\title{
Genetic diversity of Brazilian Pantaneiro horse and relationships among horse breeds
}

\author{
Fabiana Tavares Pires de Souza Sereno(1), José Robson Bezerra Sereno( ${ }^{(2)}$, Jose Luis Vega-Pla ${ }^{(3)}$, \\ Lucy Kelly ${ }^{(4)}$ and Juan Vicente Delgado Bermejo(5)
}

\begin{abstract}
(1)Universidade de Brasília, Faculdade de Agronomia e Medicina Veterinária, Brasília, DF, Brazil. E-mail: fabiana_sereno@yahoo.com.br (2)Embrapa Cerrados, Caixa Postal 08223, CEP 73310-970 Planaltina, DF, Brazil. E-mail: sereno@cpac.embrapa.br (3)Servicio de Cría Caballar y Remonta, Laboratorio de Investigación Aplicada, Apartado Oficial Sucursal 2, Córdoba, España. E-mail: jvegpla@oc.mde.es (4)Universidad de la República, Facultad de Veterinaria, Departamento de Biología Celular y Molecular, Montevideo, Uruguay. E-mail: gokelly@adinet.com.uy (5)Universidad de Córdoba, Facultad de Veterinaria, Departamento de Genética, Córdoba, España. E-mail: id1debej@lucano.uco.es
\end{abstract}

\begin{abstract}
The objective of this work was to evaluate the genetic diversity of Brazilian Pantaneiro horse by microsatellite markers, investigate the effect of genetic bottlenecks and estimate genetic differentiation among four horse breeds. Genetic variation was estimated through allele frequencies and mean breed heterozygosity. Nei's genetic distances among the breeds Pantaneiro, Thoroughbred, Arabian, Spanish Pure Breed (Andalusian), and Uruguay Creole were calculated, and it was used to construct an UPGMA dendrogram. Clustering at different $\mathrm{K}$ values was calculated to infer population structure and assign individuals to populations. Nei's distances showed a minimum distance between Pantaneiro horse and Spanish Pure Breed (0.228), and similar distances from Spanish Pure Breed to Thoroughbred and to Arabian (0.355 and 0.332). It was observed a great level of diversity, clear distance from Pantaneiro horse to other breeds, and genetic uniformity within breed. It was verified a certain level of substructure of Pantaneiro horse showing no influences from the other studied breeds.
\end{abstract}

Index terms: Equus caballus, animal conservation, molecular markers, microsatellites, genetic resources conservation.

\section{Diversidade genética do cavalo Pantaneiro e relações com outras raças de eqüinos}

\begin{abstract}
Resumo - O objetivo deste trabalho foi avaliar a variabilidade genética do cavalo Pantaneiro, por meio de marcadores microssatélites, investigar o efeito genético de "bottlenecks" e estimar a variação genética entre quatro raças de cavalo. A diversidade genética foi estimada por meio da frequiência de alelos e da média de heterozigosidade por raças. A distância genética de Nei foi calculada para as raças Pantaneiro, Puro Sangue Inglês, Árabe, Puro Sangue Espanhol e Crioulo Uruguaio. O agrupamento em diferentes valores de K foi calculado para inferir a estrutura da população e determinar indivíduos às populações. A distância de Nei mostrou distância mínima entre o cavalo Pantaneiro e o Puro Sangue Espanhol $(0,228)$, e entre o Puro Sangue Espanhol e o Puro Sangue Inglês e o Árabe ( 0,355 e 0,332 , respectivamente). Foi observada grande diversidade genética dentro da raça Pantaneiro, evidente distância desta raça em relação às demais raças estudadas, e uniformidade genética dentro da raça. Verificou-se certo nível de subestruturação no cavalo Pantaneiro, sem demonstrar influência das outras raças estudadas.
\end{abstract}

Termos para indexação: Equus caballus, conservação animal, marcadores moleculares, microssatélites, conservação de recursos genéticos.

\section{Introduction}

The wide use and conservation of Pantaneiro horse, bred in Brazilian Pantanal, was based in its functional ability to work with cattle, and its adaptation to harsh environmental conditions. The breed was preferred by cattle owners, mainly for cattlemen moving in the area.
The Pantaneiro horse nucleus, at Estação Experimental Fazenda Nhumirim, of Embrapa Pantanal (Corumbá, MS, Brazil), was created in 1988, and many research studies were developed with the objective of characterizing Pantaneiro breed.

Within the framework of breed conservation, genetic characterization is important in guarding breed integrity 
and is a prerequisite for managing genetic resources (Bjørnstad \& Røed, 2002). Genetic characterization is the first step in breed conservation and may have implications for future breeding strategies. Ease and accuracy of typing, together with high levels of polymorphism and spread distribution in the genome, make microsatellite loci an attractive potential source of information about population histories and evolutionary processes (Goldstein \& Schlötterer, 1999). Among molecular markers, microsatellites are considered suitable for biodiversity evaluation, owing to their codominant inheritance, high heterozygosity, ease and reliability of scoring, ubiquitous presence throughout the genome and high degree of polymorphism (Takezaki \& Nei, 1996). Horse breeds around the world have been analyzed by microsatellites, including the Rutuertas horse (Vega-Pla et al., 2005), Spanish Celtic breeds (Cañon et al., 2000), and various European and Asian breeds (Vilà et al., 2001; Tozaki et al., 2003). Pantaneiro breed was genetically characterized by red blood cell alloantigen, blood group loci and biochemical genetic loci (Cothran et al., 1998).

According to Food and Agriculture Organization recommendations, highly polymorphic microsatellite markers are the method for investigating genetic relationships and breed differentiation. This method also provides information for establishing preservation priorities for livestock breeds (Barker, 1999).
The objective of this study was to evaluate genetic variability in Pantaneiro horse, by microsatellites markers, investigate the effect of genetic bottlenecks and estimate genetic differentiation among four horse breeds.

\section{Materials and Methods}

Samples of 260 horses from the following populations were used: Pantaneiro $(\mathrm{N}=101)$, Thoroughbred $(\mathrm{N}=45)$, Arabian $(\mathrm{N}=45)$, Spanish Pure Breed $(\mathrm{N}=44)$ and Uruguay Creole $(\mathrm{N}=25)$. Genomic DNA of Pantaneiro horse breeding nucleus, belonging to Estação Experimental Fazenda Nhumirim, was prepared from hair roots (Kawasaki, 1990), collected from 101 animals distributed as follows: three stallions; 71 adults (40 males and 31 females); and 27 youngsters (14 males and 13 females). For the other breeds, genomic DNA was extracted from whole blood using the salting out procedure of Miller et al. (1988).

Twelve microsatellite markers recommended by the Equine Genetics and Thoroughbred Parentage Testing Standardization Committee of the International Society for Animal Genetics (ISAG) (Hoffmann et al., 2004), with known positions, were used in this work (Table 1). Genetic diversity of Pantaneiro horses was compared with Spanish Pure Breed, Arabian, Thoroughbred and Uruguay Creole animals. Samples of these animals were

Table 1. Characteristics of 12 microsatellite loci used in this study.

\begin{tabular}{|c|c|c|c|c|}
\hline $\begin{array}{l}\text { Microsatellite } \\
\text { locus }\end{array}$ & $\begin{array}{l}\text { Chromosome and } \\
\text { location }\end{array}$ & $\begin{array}{c}\text { Primer sequences } \\
\text { (forward and reverse) }\end{array}$ & $\begin{array}{l}\text { Allele size } \\
\text { range (bp) }\end{array}$ & Reference \\
\hline VHL20 & 30 & $\begin{array}{l}\text { CAAGTCCTCTTACTTGAAGACTAG } \\
\text { AACTCAGGGAGAATCTTCCTCAG }\end{array}$ & $89-107$ & $\begin{array}{l}\text { Van Haeringen et al. } \\
\text { (1994) }\end{array}$ \\
\hline AHT4 & 24 & $\begin{array}{l}\text { AACCGCCTGAGCAAGGAAGT } \\
\text { GCTCCCAGAGAGTTTACCCT }\end{array}$ & $138-170$ & Binns et al. (1995) \\
\hline AHT5 & 8 & $\begin{array}{l}\text { ACGGACACATCCCTGCCTGC } \\
\text { GCAGGCTAAGGGGGCTCAGC }\end{array}$ & $128-156$ & Binns et al. (1995) \\
\hline ASB2 & 15 & $\begin{array}{l}\text { CCTTCCTGTAGTTTAAGCTTCTG } \\
\text { CACAACTGAGTTCTCTGATAGG }\end{array}$ & $222-256$ & Breen et al. (1997) \\
\hline ASB17 & 2 & $\begin{array}{l}\text { GAGGGCGGTACCTTTGTACC } \\
\text { CACAACTGAGTTCTCTGATAGG }\end{array}$ & $89-131$ & Breen et al. (1997) \\
\hline ASB23 & 3 & $\begin{array}{l}\text { GCAAGGATGAAGAGGGCAGC } \\
\text { CTGGTGGGTTAGATGAGAAGTC }\end{array}$ & $179-213$ & Lear et al. (1999) \\
\hline HMS3 & 9 & $\begin{array}{l}\text { CCAACTCTTTGTCACATAACAAGA } \\
\text { CCATCСТCACTTTTTCACTTTGTT }\end{array}$ & $150-174$ & Guerín et al. (1994) \\
\hline HMS6 & 4 & $\begin{array}{l}\text { GAAGCTGCCAGTATTCAACCATTG } \\
\text { CTCCATCTTGTGAAGTGTAACTCA }\end{array}$ & $153-171$ & Guerín et al. (1994) \\
\hline HMS7 & 1 & $\begin{array}{l}\text { CAGGAAACTCATGTTGATACCATC } \\
\text { TGTTGTTGAAACATACCTTGACTGT }\end{array}$ & $167-191$ & Guerín et al. (1994) \\
\hline HTG4 & 9 & $\begin{array}{l}\text { CTATCTCAGTCTTGATTGCAGGAC } \\
\text { СТСССТСССТСССТСТGTTCTC }\end{array}$ & $127-141$ & Ellegren et al. (1992) \\
\hline HTG10 & 21 & $\begin{array}{l}\text { CAATTCCCGCCCCACCCCCGGCA } \\
\text { TTTTTATTCTGATCTGTCACATTT }\end{array}$ & $89-115$ & Marklund et al. (1994) \\
\hline LEX33 & 4 & $\begin{array}{l}\text { TTTAATCAAAGGATTCAGTTG } \\
\text { TTTCTCTTCAGGTGTCCTC }\end{array}$ & $194-220$ & Shiue et al. (1999) \\
\hline
\end{tabular}


provided by Laboratorio de Investigación Aplicada del Servicio de Cría Caballar y Remonta, Córdoba, Spain. The genotyping assays were performed during 2002, by Laboratório de Investigación Aplicada del Servicio de Cría Caballar y Remonta.

Amplification through PCR was performed in a final volume of $15 \mu \mathrm{L}$ : $10 \mathrm{ng}$ of genomic DNA, $20 \mathrm{mM}$ Tris$\mathrm{HCl}(\mathrm{pH} 8.4), 1 \mu \mathrm{L} \mathrm{Cl}_{2} \mathrm{Mg}(50 \mathrm{mM}), 0.2 \mu \mathrm{L}$ of each dNTPs $(25 \mathrm{mM}), 5 \mu \mathrm{L}$ primer and 0.2 Taq DNA polymerase. Amplification through PCR was carried out in two multiplex reactions (M1 and M2) using different fluorochromes for similar-sized microsatellites: M1 = ATH4, AHT5, ASB17, ASB23, HMS6, HMS7, HTG4 and VHL20; M2 = HMS3, ASB2, HTG10 and LEX33. Amplification through PCR was carried out in a PTC 100 thermocycler as follows: an initial denaturation step for $10 \mathrm{~min}$ at $95^{\circ} \mathrm{C}$, followed by 30 cycles at $95^{\circ} \mathrm{C}$ for $45 \mathrm{~s}, 56-60^{\circ} \mathrm{C}$ for $45 \mathrm{~s}, 75^{\circ} \mathrm{C}$ for $1 \mathrm{~min}$, and a last extension step of $72^{\circ} \mathrm{C}$ for $10 \mathrm{~min}$. Amplified fragments were separated on $6 \%$ polyacrylamide gel electrophoresis at an ABI 377XL automatic sequencer, and gels were read using Genescan Analysis v3.2.1 software. Size analyses of separated DNA fragments were performed with Genotyper v.2.5; the internal size standard was used for sizing alleles. Reference samples distributed by ISAG were used to standardize allele sizes.

Allelic frequencies and number of alleles per locus were estimated by direct counting. Expected and observed heterozygosities were calculated using tools for population genetic analysis - TFPGA v.1.3 (Miller, 1997). Genetic variation was estimated by microsatellite allele frequencies in each population and HardyWeinberg equilibrium (HWE) tests were conducted with GENEPOP v.3.1c program (Raymond \& Rousset, 1995). Polymorphic information contents (PIC) index was calculated using Excel (Botstein et al., 1980).

The $f$-statistic value for each locus was calculated (Weir \& Cockerham, 1984) with GENEPOP v.3.1c program, and the coefficient of gene differentiation $\left(\mathrm{G}_{\mathrm{ST}}\right)$ was estimated by DISPAN program (Ota, 1993). This statistical test is analogous to Wright's $f$-statistic value and measures the deficit or the excess of heterozygotes which could exist in Pantaneiro breed. Multilocus parameters of genetic differentiation of populations (Fit, Fis and Fst) and their errors following jackknife over locus procedure were calculated with the software Genetix v.4.05 (Belkhir et al., 2003).

Pantaneiro horse was also evaluated for any recent genetic bottlenecks by sign and standardized difference tests related to population, in order to detect the presence of any significant heterozygotic excess under infinite allele (IAM), as well as by stepwise-mutation (SMM) models based on the bottleneck computer program v.1.1.02 (Cornuet \& Luikart, 1996). These methods are based on the premise that populations experiencing recent severe reduction in size develop an excess of heterozygosity at selectively neutral loci, related to heterozygosity expected at mutation-drift equilibrium.

Nei's distance $\left(D_{A}\right)$ (Takezaki \& Nei, 1996) and Reynolds' distance ( $\mathrm{D}_{\text {Reynolds }}$ ) (Reynolds et al., 1983) were used for short divergence, and were calculated under a pure genetic drift model (excluding mutations and admixtures) for Pantaneiro, Thoroughbred, Arabian, Spanish Pure Breed (Andalusian), and Uruguay Creole horses. Estimation for $\mathrm{D}_{\mathrm{A}}$ distance was made through DISPAN (Ota, 1993), and for $\mathrm{D}_{\text {Reynolds }}$ distance through TFPGA program v.1.3 (Miller, 1997).

The $\mathrm{D}_{\mathrm{A}}$ distance was used for phylogeny tree construction based on the neighbour-joining algorithm (Saitou \& Nei, 1987). A neighbour-joining tree using individual animals as operational taxonomic units (OTUs) was constructed with a distance matrix derived from the simple allele-sharing statistic suggested by Bowcock et al. (1994). The distance matrix was produced using MICROSAT v.1.5b (Minch, 1998) based on unweighted pair group method with arithmetic mean - UPGMA (Ruiz-Linares, 1999). The PHYLIP package v.3.57c (Felsestein, 1995) was used to construct the tree of the distance matrix. In order to construct the tree, all breeds studied were included in the analysis.

The Structure v.2.1 program (Prichard et al., 2000) was used to calculate the clustering at different $K$ values, which is the number of assumed populations using the admixture model, in which an individual may have mixed ancestry. It is based on a Bayesian clustering algorithm that uses multilocus genotypes to infer population structure and assign individuals to populations (Falush et al., 2003). The number of hypothetical clusters (K) was four to eight, and one-million repetitions of the Markov Chain Monte Carlo algorithm were used after one-hundred-thousand repetitions in the burning period, and ran three independent simulations of this length for each $\mathrm{K}$ to evaluate stability.

\section{Results and Discussion}

All amplified loci were polymorphic in all breeds, with a total of 107 different alleles detected across the loci 
analyzed. The number of alleles varied between six (HTG4) and 13 (ASB17) with a mean of 8.9 alleles.

The alleles VHL20-K, LEX33-G, LEX33-T, ASB23-T, HMS7-P and ASB17-I were present exclusively in Pantaneiro horse, and this breed showed greater HardyWeinberg disequilibrium in AHT4, ASB17 and HMS6 markers with heterozygote excess. The greater number of alleles in Pantaneiro horse may be a consequence of strategies, such as selection and use of different stallions, adopted by the breeding nucleus to prevent inbreeding and preserve genetic variation within the population.

The importance of maintaining genetic diversity in domestic species is related to the need for introducing genetic improvements into particular selected breeds, and to facilitate rapid adaptation to potential changes in breeding goals (Notter, 1999). Pantaneiro horse breed was generated from Spanish and Portuguese horses introduced during the colonization period and are well adapted to Pantanal environmental conditions.

The heterozygosity and mean number of alleles in Pantaneiro horse reflect a high genetic variability (Table 2). HWE was tested for all breed-locus combinations. The microsatellite locus VHL20 showed HWE deviations in three populations, and ASB2 in two populations. Significant HWE deviations were detected in Pantaneiro with five loci (VHL20, ASB2, AHT5, ASB17 and HMS6), and PSI populations with three loci (HTG4, HMS3 and LEX33). There was significant HWE deviation $(\mathrm{p}<0.1)$, considering heterozygote excess, in Pantaneiro horse (three cases), in Thoroughbred (two cases) and in Arabian horse (one case). No significant
HWE deviations were found within populations considering heterozygote deficiency.

All loci evaluated in the present work showed PIC values higher than 0.5 , and were considered highly informative (Botstein et al., 1980) (Table 2). Observed and expected heterozygosities were similar to other studied breeds (Guérin et al., 1994; Cañon et al., 2000). Pantaneiro horse population, compared with other breeds, has a genetic structure; the number of alleles and heterozygosity value demonstrated a high degree of genetic diversity within the breeding nucleus.

Cothran et al. (1998) observed an excess of heterozygosity in four Pantaneiro populations, and a single statistically significant deviation from HardyWeinberg expectations. They concluded that levels of genetic variability within Pantaneiro breed were at about the normal level for horses. The genetic variability data do not suggest a great deal of recent crossing of Pantaneiro with other breeds.

The $\mathrm{G}_{\mathrm{ST}}$ values for single loci ranged between 0.039 (AHT4) and 0.1138 (ASB23), and $\theta$-values ranged between 0.0398 (AHT4) and 0.1254 (HMS3) (Table 2). The $\theta$ and $\mathrm{G}_{\mathrm{ST}}$ values indicated that $8 \%$ of the total genetic variation is explained by breed differences in the horse populations, and $92 \%$ by differences among individuals. The lower $f$ values indicated homogeneous population with lower within-population-inbreeding, except for VHL20, and $\theta$ and $\mathrm{G}_{\mathrm{ST}}$ values indicated a genetic differentiation within populations.

Data of inbreeding and genetic differentiation, obtained for statistic $\mathrm{F}, f, \theta$ and $\mathrm{G}_{\mathrm{ST}}$ of each microsatellite,

Table 2. Number of alleles, range of allele sizes, polymorphic information contents index $(\mathrm{PIC})$, expected $\left(\mathrm{H}_{\mathrm{e}}\right)$ and observed $\left(\mathrm{H}_{\mathrm{o}}\right)$ heterozygosities, coefficient of gene differentiation $\left(\mathrm{G}_{\mathrm{ST}}\right)$ and F-statistics $(\theta, \mathrm{F}$ and $f)$ for each of the 12 microsatellite markers in five horse breeds.

\begin{tabular}{lcccrrrrrr}
\hline Microsatellite locus & $\mathrm{N}^{\mathrm{o}}$ of alleles & Alleles average & $\mathrm{PIC}$ & $\mathrm{H}_{\mathrm{e}}$ & $\mathrm{H}_{\mathrm{o}}$ & \multicolumn{1}{c}{$\mathrm{G}_{\mathrm{ST}}$} & \multicolumn{1}{c}{$\mathrm{F}$} \\
\hline VHL20 & 9 & 7.2 & 0.8261 & 0.85 & 0.7038 & 0.0688 & 0.0651 & 0.1759 & 0.1185 \\
HTG4 & 6 & 5.2 & 0.6847 & 0.72 & 0.6807 & 0.0746 & 0.0800 & 0.0779 & -0.0023 \\
AHT4 & 9 & 6.2 & 0.7675 & 0.80 & 0.8192 & 0.0390 & 0.0398 & -0.0158 & -0.0580 \\
HMS7 & 8 & 5.6 & 0.7553 & 0.79 & 0.6961 & 0.0860 & 0.0913 & 0.1339 & 0.0468 \\
ASB2 & 12 & 8.0 & 0.8275 & 0.85 & 0.8000 & 0.0528 & 0.0487 & 0.0671 & 0.0193 \\
ASB17 & 13 & 9.2 & 0.8192 & 0.84 & 0.8500 & 0.0654 & 0.0692 & 0.0031 & -0.0711 \\
AHT5 & 8 & 6.2 & 0.7291 & 0.76 & 0.6807 & 0.1038 & 0.1039 & 0.1291 & 0.0281 \\
HMS6 & 7 & 5.6 & 0.7272 & 0.76 & 0.7384 & 0.0772 & 0.0784 & 0.0483 & -0.0326 \\
ASB23 & 8 & 6.4 & 0.7990 & 0.82 & 0.7730 & 0.1138 & 0.0941 & 0.0841 & -0.0110 \\
HTG10 & 10 & 8.2 & 0.8324 & 0.85 & 0.7576 & 0.0923 & 0.0960 & 0.1304 & 0.0380 \\
HMS3 & 8 & 6.4 & 0.7728 & 0.80 & 0.7153 & 0.1027 & 0.1254 & 0.1356 & 0.0117 \\
LEX33 & 9 & 5.8 & 0.7437 & 0.77 & 0.7307 & 0.0755 & 0.0843 & 0.0763 & -0.0095 \\
\hline
\end{tabular}


are useful to evaluate each marker's behavior. Marker VHL20 was the only microsatellite with values above of the desirable $10 \%$, and the remainder markers presented $f$ values close to zero. The $f$-statistics values for all loci (Fit $=0.09 \pm 0.02$, Fis $=0.01 \pm 0.01$, and Fst $=0.08 \pm 0.01)$ indicated a clear genetic differentiation between studied populations showing low inbreeding between breeds. Analysis of genetic relationships by Cothran et al. (1998) showed that Pantaneiro was clearly descendent from Iberian Peninsula, and that it was most closely related to other Brazilian breeds; this genetic variation indicated normal variation levels for horses and that there is no indication of inbreeding.

The proportion of genetic variation attributed to differences between breeds was about $8 \%$ of the total variation, with the remainder corresponding to differences between individuals. This is similar to the $8 \%$ differentiation observed between Spanish Celtic horse breeds (Cañon et al., 2000), and somewhat lower than the observed (12\%) for horses of Norwegian (Bjørnstad et al., 2000) and German breeds (Aberle et al., 2004).

The result obtained with Nei's distance comparing five breeds showed a minimum distance between Pantaneiro and Arabian (0.204) horses, and between Pantaneiro and Spanish Pure Breed (0.228) (Table 3). Reynold's distance showed lower distance between Pantaneiro and Spanish Pure Breed, and between Pantaneiro and Arabian. The genetic distance values observed in the five populations and the individual distance analysis showed Pantaneiro horse with unique identity despite this genetic variability.

The neighbour-joining tree $\left(D_{A}\right)$ showed a clear subdivision of the breeds, and Pantaneiro horse was more closely related to Spanish Pure Breed and Arabian (Figure 1). This could be explained by some influence from Spanish Pure Breed, in the original breed formation, and from Arabian in more recent years. The genetic distance values in breed populations showed that Pantaneiro horse was genetically distinct from the other breeds; individual distance and analysis confirm genetic differentiation between breeds and Pantaneiro homogeneity, despite great genetic variability.

Infinite allele model (IAM) was greater in all microsatellites studied, and in nine microsatellites in stepwise-mutation model (SMM) (Table 4). Heterozygosity excess $(\mathrm{p}<0.05)$ indicated that Pantaneiro population could suffer a bottleneck, but based in SMM model this bottleneck did not occur in recent period.

As discussed by Luikart et al. (1998), a bottlenecked population might not have a distorted allelic distribution for the following reasons: bottleneck was not recent or narrow enough to be detectable; not enough polymorphic loci or individuals were sampled to provide sufficient power to detect a bottleneck; individuals sampled were not representative of the bottlenecked population; a demographic bottleneck occurred, but not a genetic one; and bottlenecked population was not completely isolated and contained genes from immigrants that obscured genetic effects of the bottleneck. The first and last reasons are the most probable for Pantaneiro horse.

When a tree was constructed from distance matrices using individual animals as OTUs, an underlying genetic structure was more immediately apparent (Figure 2). With the possible exception of Uruguay Creole, Pantaneiro breed showed a remarkable degree of breed clustering, as did other breeds in this work. Only 32 animals of the 260 studied did not cluster with animals from the same population. Some breeds were very tightly clustered. All of the microsatellite loci studied indicated that the topology of Pantaneiro breed is particularly robust. Close inspection of Pantaneiro group showed a clear subdivision of population, and 16 animals split in

Table 3. Reynolds' genetic distance - below the diagonal - and Nei's distance - above the diagonal -, among horse breeds Spanish Pure Breed (PRE), Arabian, Thoroughbred (PSI), Pantaneiro, and Uruguay Creole.

\begin{tabular}{|c|c|c|c|c|c|}
\hline Breed & PRE & Arabian & PSI & Pantaneiro & Uruguay Creole \\
\hline$\overline{\mathrm{PRE}}$ & - & 0.3558 & 0.3325 & 0.2283 & 0.2809 \\
\hline Arabian & 0.1059 & - & 0.4931 & 0.2042 & 0.2985 \\
\hline PSI & 0.0966 & 0.1428 & - & 0.3751 & 0.3561 \\
\hline Uruguay Creole & 0.0784 & 0.0924 & 0.1020 & 0.0651 & - \\
\hline
\end{tabular}


other groups, especially Uruguay Creole, indicated possible similar characteristics to other breeds.

In Figure 3, each individual is represented by a thin vertical line, which is divided in K colored segments which represent the fraction of each individual belonging to each

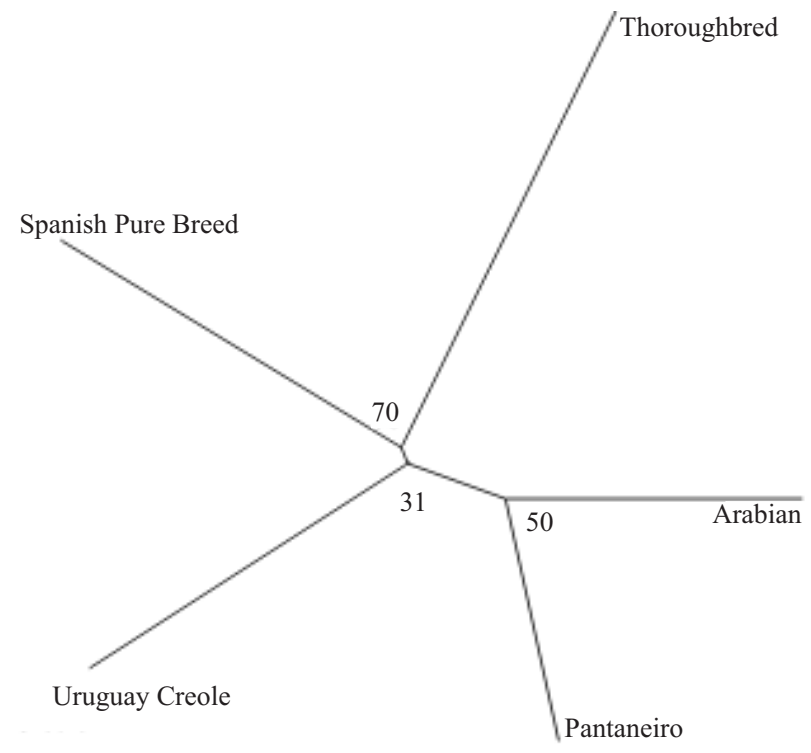

0.1

Figure 1. Dendrogram showing the genetic relationships among Pantaneiro, Uruguay Creole, Spanish Pure Breed, Arabian, and Thoroughbred populations based on Nei's distance. Robustness was calculated with one thousand bootstrap replications. inferred cluster. Black lines separate individuals of the different populations. Optimum clustering value was $K=7$. When $K=4$, a cluster was formed with Spanish Pure Bred and Uruguay Creole populations. In case of $\mathrm{K}=5$, Pantaneiro and Uruguay Creole share DNA profiles. From K6 to K8, Pantaneiro showed a substructure without demonstrating influences from the rest of breeds.

Pantaneiro horse has maintained a level of genetic diversity comparable to that of other horse breeds (Bjørnstad et al., 2000; Cañon et al., 2000; Vilà et al., 2000). The differences obtained from microsatellite analyses are in agreement with the results of Cothran et al. (1998), which characterized red blood cell alloantigen, blood group loci and biochemical genetic loci of four Pantaneiro horse populations. The origin of Pantaneiro horse and Uruguay Creole goes back to the colonization, but although they have geographically closely located, there was a clear genetic differentiation between them, as indicated by microsatellites analyses.

Pantaneiro horse population was structured with a high level of genetic diversity, and was situated between the other breeds. Comparing these data with the ones of other breeds confirms that Pantaneiro breed conserves high genetic variability. The results from microsatellite analyses are in agreement with those obtained by Cothran et al. (1998), which characterized four populations of Pantaneiro horse. They observed the greatest genetic variability within this breed, probably because of its wide genetic base and heterogeneity within the studied population.

Table 4. Results of the bottleneck detection tests on Pantaneiro breed showing infinite allele (IAM) and stepwise-mutation $(\mathrm{SMM})$ models, with heterozygosity excess $\left(\mathrm{H}_{\mathrm{e}}\right)$, SD and probabilities $(\mathrm{Pr})^{(1)}$.

\begin{tabular}{|c|c|c|c|c|c|c|c|c|c|}
\hline \multirow[t]{2}{*}{ Microsatellite locus } & \multirow[t]{2}{*}{$\mathrm{N}$} & \multirow[t]{2}{*}{ ko } & \multirow[t]{2}{*}{$\mathrm{H}_{\mathrm{o}}$} & \multicolumn{3}{|c|}{ IAM } & \multicolumn{3}{|c|}{ SMM } \\
\hline & & & & $\mathrm{H}_{\mathrm{e}}$ & SD & $\mathrm{Pr}$ & $\mathrm{H}_{\mathrm{e}}$ & SD & $\mathrm{Pr}$ \\
\hline VHL20 & 198 & 9 & 0.863 & 0.68 & 0.12 & 0.00 & 0.80 & 0.05 & 0.03 \\
\hline HTG4 & 202 & 6 & 0.717 & 0.55 & 0.16 & 0.12 & 0.69 & 0.08 & 0.48 \\
\hline AHT4 & 202 & 8 & 0.806 & 0.64 & 0.14 & 0.04 & 0.77 & 0.05 & 0.33 \\
\hline HMS7 & 200 & 7 & 0.759 & 0.60 & 0.15 & 0.09 & 0.74 & 0.07 & 0.50 \\
\hline ASB2 & 202 & 9 & 0.839 & 0.68 & 0.12 & 0.01 & 0.80 & 0.04 & 0.21 \\
\hline ASB17 & 202 & 11 & 0.791 & 0.73 & 0.10 & 0.33 & 0.84 & 0.04 & 0.09 \\
\hline AHT5 & 202 & 7 & 0.760 & 0.60 & 0.14 & 0.07 & 0.74 & 0.06 & 0.48 \\
\hline HMS6 & 202 & 6 & 0.765 & 0.54 & 0.17 & 0.04 & 0.69 & 0.08 & 0.18 \\
\hline ASB23 & 202 & 8 & 0.825 & 0.63 & 0.13 & 0.01 & 0.78 & 0.05 & 0.16 \\
\hline HTG10 & 202 & 9 & 0.833 & 0.68 & 0.12 & 0.02 & 0.80 & 0.05 & 0.27 \\
\hline HMS3 & 202 & 7 & 0.694 & 0.60 & 0.14 & 0.31 & 0.75 & 0.06 & 0.17 \\
\hline LEX33 & 202 & 7 & 0.739 & 0.69 & 0.16 & 0.16 & 0.74 & 0.06 & 0.41 \\
\hline
\end{tabular}

${ }^{(1)}$ ko and $\mathrm{H}_{\mathrm{o}}$ values are allele numbers and observed heterozygosity, respectively; $\mathrm{H}_{\mathrm{e}}$, SD and Pr are average heterozygosity, tipic desviation and probabilities $\mathrm{H}>\mathrm{H}_{\mathrm{e}}$, respectively, in infinite allele (IAM) and stepwise mutation (SMM) models. 


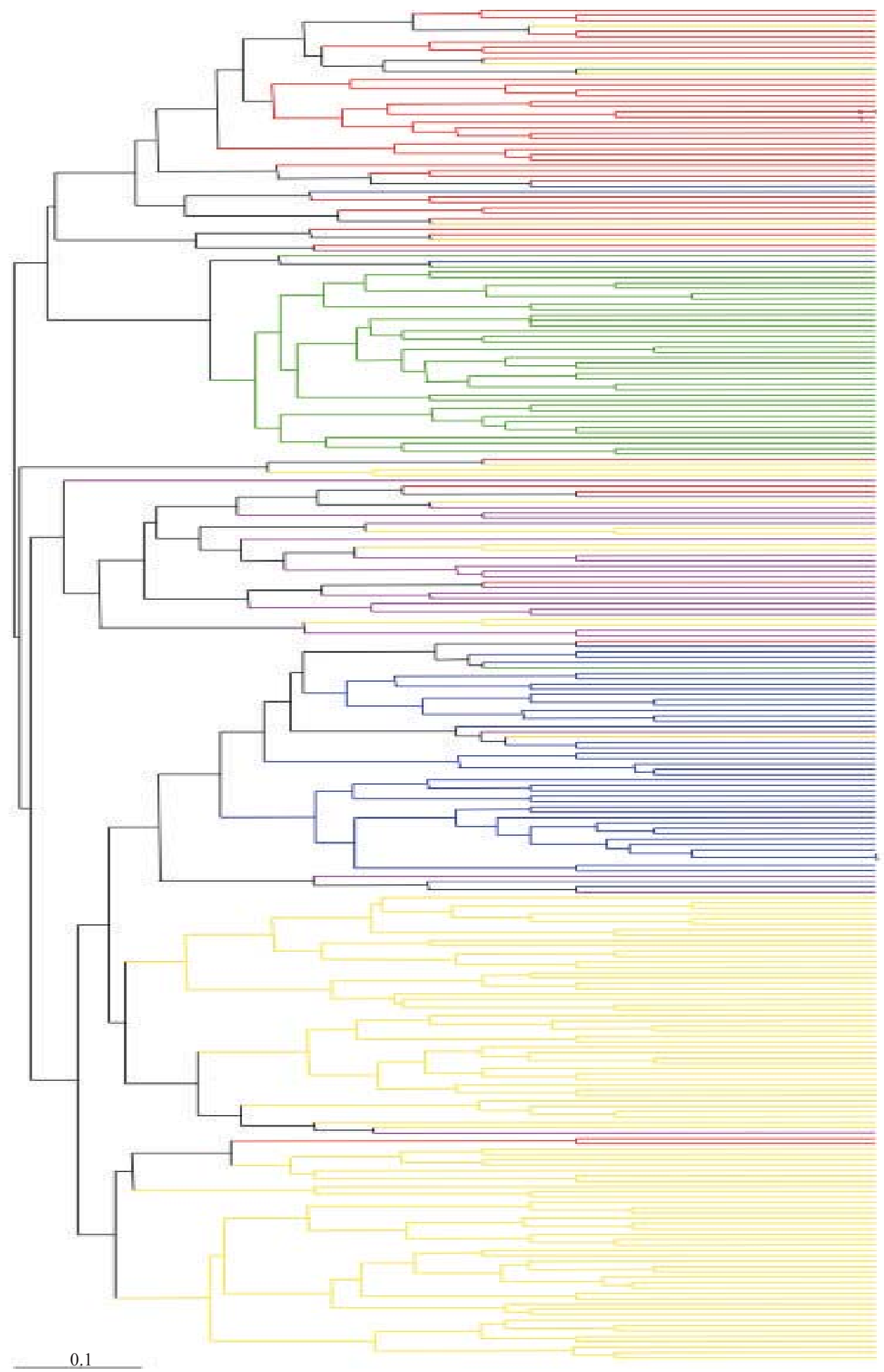

Spanish Pure Breed

Thoroughbred

\section{Uruguay Creole}

Arabian

Pantaneiro

Figure 2. Dendrogram showing cluster analysis (UPGMA) relationship among 260 animals from Pantaneiro, Uruguay Creole, Spanish Pure Breed, Arabian, and Thoroughbred populations. 

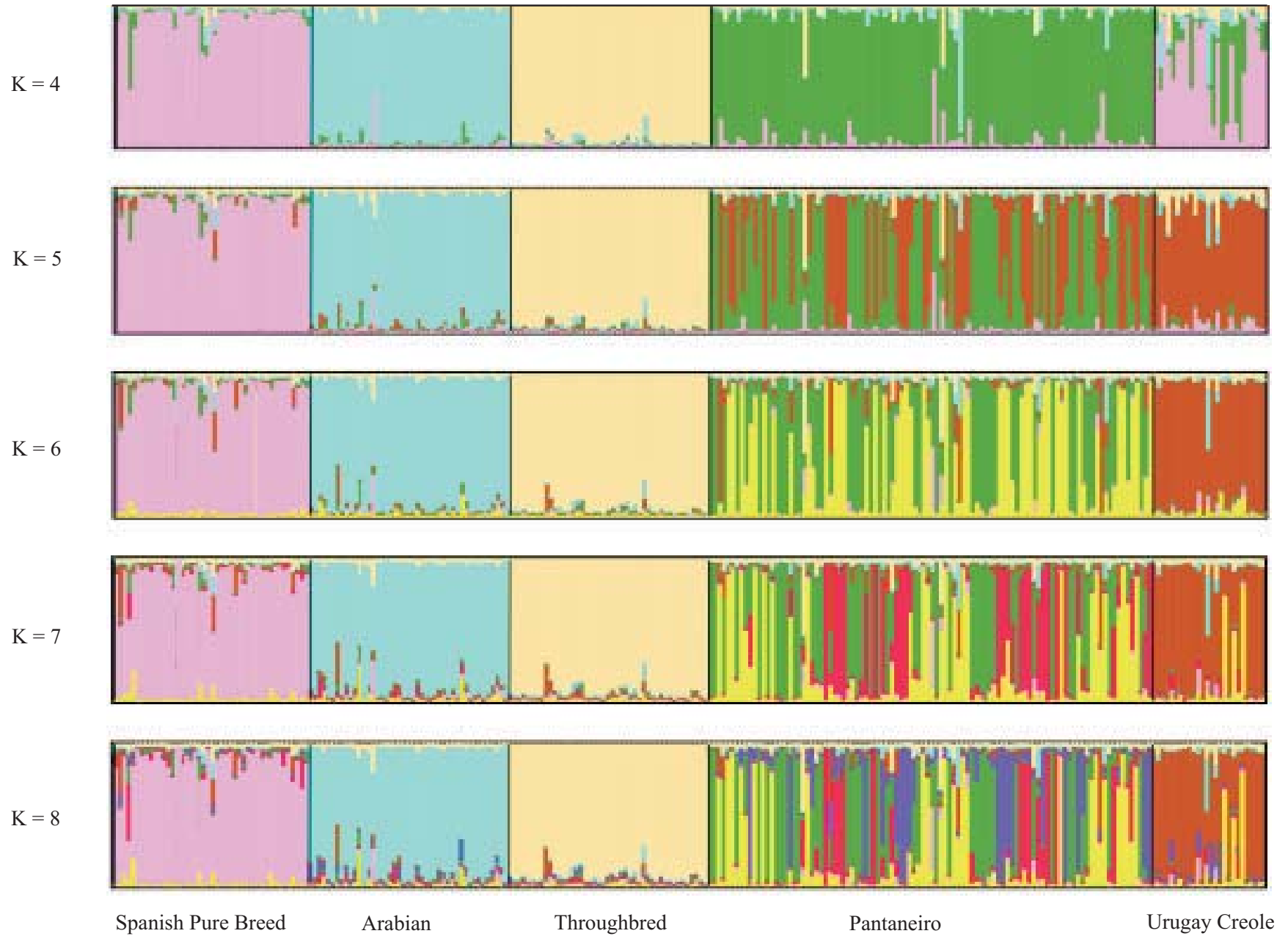

Figure 3. Graphical presentation of the population structure analyses of a sample of 260 horses (a priori defined four breeds). Each horse is represented by a single vertical line, broken into K colour segments, with lengths proportional to the estimated membership of the inferred cluster.

\section{Conclusion}

Pantaneiro horse population is structured with a high level of genetic diversity, and has a unique identity despite this genetic variability.

\section{Acknowledgements}

To Embrapa Pantanal, for samples of the collection of Pantaneiro horse; to Laboratorio de Investigación Aplicada de Córdoba, for their support on genotyping analysis; to Maria Luiza Nicodemo, for English review.

\section{References}

ABERLE, K.S.; HAMANN, H.; DRÖGEMÜLLER, C.; DISTL, O. Genetic diversity in German draught horse breeds compared with a group of primitive, riding and wild horses by means of microsatellite DNA markers. Animal Genetics, v.35, p.270-277, 2004.

BARKER, J.S.F. Conservation of livestock breed diversity. Animal Genetics Research Information, v.25, p.33-43, 1999.

BELKHIR, K.; BORSA, P.; CHIKHI, L.; GOUDET, J.; BONHOMME, F. GENETIX: logiciel sous WindowsTM pour la génétique des populations. Laboratoire Génome, Populations, Interactions, CNRS UMR 5000. Montpellier: Université de Montpellier II, 2003.

BINNS, M.M.; HOLMES, N.G.; HOLLIMAN, A.; SCOTT, A.M. The identification of polymorphic microsatellite loci in the horse and their use in Thoroughbred parentage testing. British Veterinary Journal, v.151, p.9-15, 1995.

BJøRNSTAD, G.; GUNBY, E.; RøED, K.H. Genetic structure of Norwegian horse breeds. Journal of Animal Breeding Genetics, v.117, p.307-317, 2000. 
BJøRNSTAD, G.; RøED, K.H. Evaluation of factors affecting individual assignment precision using microsatellite data from horse breeds and simulated breed crosses. Animal Genetics, v.33, p.264270, 2002

BOTSTEIN, D.; WHITE, R.L.; SKOLNICK, H.; DAVIS, R.W. Construction of a genetic linkage map in man using restriction fragment length polymorphism. American Journal of Animal Genetics, v.32, p.314-331, 1980.

BOWCOCK, A.M.; RUIZ-LINARES, A.; TOMFOHRDE, J.; MINCH, E.; KIDD, J.R.; CAVALLI-SFORZA, F.F. High resolution of human evolutionary trees with polymorphic microsatellites. Nature, v.368, p.455-457, 1994.

BREEN, M.; LINDGREN, G.; BINNS, M.M.; NORMAN, J.; IRVIN, Z.; BELL, K.; SANDBERG, K.; ELLEGREN, H. Genetical and physical assignments of equine microsatellites: first integration of anchored markers in horse genome mapping. Mammalian Genome, v.8, p.267-273, 1997.

CAÑON, J.; CHECA, M.L.; CARLEOS, C.; VEGA-PLA, J.L.; VALLEJO, M.; DUNNER, S. The genetic structure of Spanish Celtic horse breeds inferred from microsatellite data. Animal Genetics, v.31, p.39-48, 2000.

CORNUET, J.M.; LUIKART, G. Description and power analysis of two tests for detecting recent population bottlenecks from allele frequency data. Genetics, v.144, p.2001-2014, 1996.

COTHRAN, E.G.; SANTOS, S.A.; MAZZA, M.C.M.; LEAR, T.L.; SERENO, J.R.B. Genetics of the Pantaneiro horse of the Pantanal region of Brazil. Genetics and Molecular Biology, v.21, p.343-349, 1998.

ELLEGREN, H.; JOHANSSON, M.; SANDBERG, K.; ANDERSSON, L. Cloning of highly polymorphic microsatellites in horse. Animal Genetics, v.23, p.133-142, 1992.

FALUSH, D.; STEPHENS, M.; PRITCHARD, J.K. Inference of population structure using multilocus genotype data: linked loci and correlated allele frequencies. Genetics, v.164, p.1567-1587, 2003.

FELSESTEIN, J. PHYLIP: (Phylogeny Inference Package). Washington: University of Washington, 1995. Version 3.5c.

GOLDSTEIN, D.B.; SCHLÖTTERER, C. Microsatellites: evolution and applications. New York: Oxford University Press, 1999. 352p.

GUÉRIN, G.; BERTAUD, M.; AMIGUES, Y. Characterization of seven new horse microsatellites: HMS1, HMS2, HMS3, HMS5, HMS6, HMS7, HMS8. Animal Genetics, v.25, p.62, 1994.

HOFFMANN, I.; MARSAN, P.A.; BARKER, J.S.F.; COTHRAN, E.G.; HANOTTE, O.; LENSTRA, J.A.; MILAN, D.; WEIGEND, S.; SIMIANER, H. New MoDAD marker sets to be used in diversity studies for the major farm animal species: recommendations of a joint ISAG/FAO working group. Available at: http://dad.fao.org/cgi-bin/ getblob.cgi?sid=56911a869fbe6967ale8cffe090475f9,50005882. Accessed on: May 5, 2008.
KAWASAKI, E.S. Sample preparation from blood, cells and other fluids. In: INNIS, M.A.; GELFAND, D.H.; SNINSKY, J.J.; WHITE, T.J. (Ed.). PCR protocols: a guide to methods and applications. San Diego: Academic Press, 1990. p.146-152.

LEAR, T.L.; BRANDON, R.; BELL, K. Physical mapping of ten equine dinucleotide repeat microsatellites. Animal Genetics, v.30, p.235, 1999.

LUIKART, G.; ALLENDORF, F.W.; CORNUET, J.M.; SHERWIN, W.B. Distortion of allele frequency distributions provides a test for recent population bottlenecks. Journal of Heredity, v.89, p.238-247, 1998.

MARKLUND, S.; ELLEGREN, H.; ERIKSSON, S.; SANDBERG, K.; ANDERSSON, L. Parentage testing and linkage analysis in the horse using a set of highly polymorphic microsatellites. Animal Genetics, v.25, p.19-23, 1994.

MILLER, M.P. Tools For Population Genetic Analyses (TFPGA): a Windows program for the analysis of allozyme and molecular population genetic data. Northern Arizona University, 1997. Version 1.3. (Computer software distributed by the author).

MILLER, S.A.; DYKES, D.D.; POLESKY, H.F. A simple salting out procedure for extracting DNA from human nucleated cells. Nucleic Acids Research, v.16, p.1215, 1988.

MINCH, E. MICROSAT. Standford: University of Standford, 1998.

NOTTER, D.R. The importance of genetic diversity in livestock populations of the future. Journal of Animal Science, v.77, p.61-69, 1999.

OTA, T. Distance and Phylogenetic Analysis (DISPAN). Pennsylvania State University, 1993. (Computer software distributed by the author).

PRITCHARD, J.K.; STEPHENS, M.; DONNELLY, P. Inference of population structure using multilocus genotype data. Genetics, v.155, p.945-959, 2000.

RAYMOND, M.; ROUSSET, F. GENEPOP (version 1.2): population genetics software for exact tests and ecumenicism. Journal of Heredity, v.86, p.248-249, 1995.

REYNOLDS, J.; WEIR, B.S.; COCKERHAM, C.C. Estimation of the coancestry coefficient: basis for a short-term genetic distance. Genetics, v.105, p.767-779, 1983.

RUIZ-LINARES, A. Microsatellites and the reconstruction of the history of human population. In: GOLDSTEN, D.B.; SCHLÖTTERER, C. Microsatellites: evolution and applications. New York: Oxford University Press, 1999. p.183-197.

SAITOU, N.; NEI, M. The neighbor-joining method: a new method for reconstructing phylogenetic trees. Molecular Biology and Evolution, v.4, p.406-425, 1987.

SHIUE, Y-L; BICKEL, L.A.; CAETANO, A.R.; MILLON, L.V.; CLARK, R.S.; EGGLESTON, M.L.; MICHELMORE, R.; BAILEY, E.; GUÉRIN, G.; GODARD, S.; MICKELSON, J.R.; VALBERG, S.J.; MURRAY, J.D.; BOWLING, A.T. A synteny map of the horse 
genome comprised of 240 microsatellite and RAPD markers. Animal Genetics, v.30, p.1-9, 1999.

TAKEZAKI, N.; NEI, M. Genetic distances and reconstruction of phylogenetic trees from microsatellite DNA. Genetics, v.144, p.389-399, 1996.

TOZAKI, T.; TAKEZAKI, N.; HASEGAWA, T.; ISHIDA, N.; KUROSAWA, M.; TOMITA, M.; SAITOU, N.; MUKOYAMA,

$\mathrm{H}$. Microsatellite variation in Japanese and Asian horses and their phylogenetic relationship using a European horse outgroup. Journal of Heredity, v.94, p.374-380, 2003.

VAN HAERINGE, N.H.; BOWLING, A.T.; STOTT, M.L.; LENSTRA, J.A.; ZWAAGSTRA, K.A. A highly polymorphic horse microsatellite locus: VHL20. Animal Genetics, v.25, p.207, 1994.
VEGA-PLA, J.L.; CALDERÓN, J.; RODRÍGUEZ-GALLARDO, P.P.; ALCAIDE, B.; SERENO, F.T.P.S.; COSTA, M.R.; PÉREZPINEDA, E.; DELGADO, J.V.; RICO, C. The Retuertas horse: the "missing link" in the Iberoamerican horse breeds origin? In: BODÓ, I.; ALDERSON, L.; LANGLOIS, B. (Ed.). Conservation genetics of endangered horse breeds. Netherlands: Wageningen Academic Publishers, 2005. p.167-176.

VILÀ, C.; LEONARD, J.A.; GÖTHRESTRÖM, A.; MARKLUND, S.; SANDBERG, K.; LIDÉN, K.; WAYNE, R.K.; ELLEGREN, H. Widespread origins of domestic horse lineages. Science, v.291, p.474-477, 2001.

WEIR, B.S.; COCKERHAM, C.C. Estimating F-statistics for the analysis of population structure. Evolution, v.38, p.1358-1370, 1984.

Received on June 29, 2007 and accepted on April 29, 2008 